\title{
Optical and Dispersion Parameters of the Al-doped ZnO Thin Film
}

\author{
A.I. Kashuba, ${ }^{1, *}$ B. Andriyevsky², H.A. Ilchuk ${ }^{1}$, R.Yu. Petrus ${ }^{1}$, T.S. Malyi ${ }^{3}$, I.V. Semkiv ${ }^{1}$ \\ ${ }^{1}$ Lviv Polytechnic National University, 12, S. Bandera St., 79646 Lviv, Ukraine \\ ${ }^{2}$ Faculty of Electronics and Computer Sciences, Koszalin University of Technology, 75-453 Koszalin, Poland \\ ${ }^{3}$ Ivan Franko National University of Lviv, 8, Kyrylo and Mefodiy St., 79005 Lviv, Ukraine
}

(Received 09 March 2021; revised manuscript received 06 August 2021; published online 20 August 2021)

\begin{abstract}
The results of studies of the dispersion of optical functions and optical constants for zinc oxide thin film doped with aluminum are presented. The deposition of Al-doped $\mathrm{ZnO}(2.5 \mathrm{wt}$. \%) thin films is performed by magnetron sputtering. Al-doped $\mathrm{ZnO}$ thin film crystallizes in a hexagonal structure (structure type $\mathrm{ZnO}$, space group $P 6_{3} m c$ (No. 186) with unit-cell dimensions $a=3.226(2) \AA$ and $c=5.155(6) \AA\left(V^{\circ}=46.49(6) \AA^{3}\right)$. Optical transmittance spectra $(300-2500 \mathrm{~nm})$ shows that the Al-doped $\mathrm{ZnO}$ thin film is of high optical quality, and the value of the optical band gap $(3.26 \mathrm{eV})$ is very close to undoped samples. The study of optical functions is performed on the basis of the experimentally measured transmission spectrum using the bypass method. The spectral behavior of optical functions, such as refractive index, extinction coefficient, absorption index, dielectric functions and optical conductivity, is established. The value of Urbach energy and the dependence of oscillator strength on the size of the band gap and the concentration of doping element are determined. It is observed an increase in Urbach energy for the Al-doped $\mathrm{ZnO}$ thin film in comparison to the undoped ones. An almost twofold increase in the optical oscillator strength value is revealed for the thin film studied. The influence of aluminum doping on the dynamic change of optical mobility, optical resistance and relaxation time is established for the first time for the studied compound. The value of the plasma frequency is also determined and its correlation with the carrier density is defined. The doping of $\mathrm{ZnO}$ thin films with aluminum leads to an increase in optical mobility, relaxation time and plasma frequency that is revealed by comparison with reference data for the undoped $\mathrm{ZnO}$. Due to good optical properties, this thin film is a good candidate as a material for optoelectronic devices.
\end{abstract}

Keywords: Thin films, Absorption, Dispersion, Refractive index, Transmission, Optical function, Relaxation time.

DOI: 10.21272/jnep.13(4).04006

PACS numbers: 78.20. - e, 78.20.Ci, 78.55.Et

\section{INTRODUCTION}

$\mathrm{ZnO}$ thin films attract considerable attention of researchers as a promising material for solar energy, gas sensors and other applications [1-7]. In the classical case, zinc oxide is a wide band gap semiconductor with high exciton binding energy of $60 \mathrm{meV}$ [8].

It is known that optical properties of semiconductor thin films depend on the deposition method $[9,10]$. Currently, various methods are used to obtain $\mathrm{ZnO}$ thin films: radio frequency $(\mathrm{RF})$ or direct current sputtering, spray pyrolysis, spin coating, metal organic chemical vapor deposition and pulsed laser deposition [5-7, 9-19].

$\mathrm{ZnO}$ is usually doped with different chemical elements to modify the optical transmittance and band gap of the corresponding thin films by changing their electrical, optical and other properties. Degree of Aldoping plays a major role in increasing the optical band gap of $\mathrm{ZnO}$ thin films and the enhancement of their optical transparency.

Doping of zinc oxide thin films results in different changes of physical properties. In most cases, doping of thin films results in an increase in the band gap value [11-13, 15-22] caused by the influence of the BursteinMoss effect [20-22] and increased contribution of defects [21] (Zn, O vacancies). In several studies [23-26], doping with different chemical elements leads to a decrease in the band gap, or the value of the band gap remains almost independent of doping.

As a consequence, the physical properties of zinc ox- ide thin films may depend on the deposition method or the alloying chemical element. Since one of the predominant applications of zinc oxide thin films is solar energy ( $\mathrm{ZnO}$ as a conductive material) and gas sensors, it is important to know the behavior of optical functions and optical constants (including optical mobility, relaxation time and optical resistance).

Aluminum (2.5 wt. \%) as the doping element and $\mathrm{RF}$ sputtering as the preparing method were chosen in the present study. Currently, no reference data on the main optical parameters (optical mobility, relaxation time, optical resistance) of $\mathrm{ZnO}: \mathrm{Al}$ thin films obtained by $\mathrm{RF}$ sputtering are available.

\section{EXPERIMENTAL DETAILS}

Al-doped $\mathrm{ZnO}$ ( $\mathrm{ZnO}: \mathrm{Al})$ thin films were deposited on glass substrates with a size of $16 \times 8 \times 1.1 \mathrm{~mm}^{3}$ by the method of high-frequency (HF) magnetron sputtering $(\sim 13.6 \mathrm{MHz})$ using a VUP-5M vacuum station (Selmi, Ukraine) [9, 27]. As a target the disc from sintered $\mathrm{ZnO}$ (purity of $99.99 \%$ ) powder with $\mathrm{Al}_{2} \mathrm{O}_{3}$ (2.5 wt.\%) admixture was used. The target-substrate distance was $60 \mathrm{~mm}$. The start and end of the process were controlled by means of a movable shutter.

The power of the HF magnetron was maintained at a level of $30 \mathrm{~W}$, and the substrate temperature was $373 \mathrm{~K}$. A high-temperature tungsten heater with a power of $300 \mathrm{~W}$ was used to heat the substrates. The temperature was controlled by means of a proportional-

\footnotetext{
*AndriyKashuba07@gmail.com
} 
integral-derivative (PID) controller for controlling heating and cooling rates, as well as for ensuring the temperature conditions of deposition.

Spectral dependences of the optical transmittance (Shimadzu UV-3600) of the title samples have been measured in the visible and near infrared regions (300$2500 \mathrm{~nm})$ at room temperature [9, 27].

\section{RESULTS AND DISCUSSION}

\subsection{The Optical Band Gap $E_{\mathrm{g}}$ and Urbach Parameter $E_{0}$}

The transmittance spectrum of $\mathrm{ZnO}: \mathrm{Al}$ thin films is given in Fig. 1. As-grown thin films are found to exhibit high transparency in the wavelength range $300-2500 \mathrm{~nm}$. Here, the average transmittance is close to $78 \%$.

To determine the thickness of the films under investigation, we can use the following equation:

$$
d=\frac{M \cdot \lambda_{1} \cdot \lambda_{2}}{2 \cdot\left(n\left(\lambda_{1}\right) \cdot \lambda_{2}-n\left(\lambda_{2}\right) \cdot \lambda_{1}\right)},
$$

where $\lambda_{1}$ and $\lambda_{2}$ are the wavelengths corresponding to the neighboring extreme points in the transmission spectrum, $M=1$ for two neighboring extrema of one type (max-max, min-min) and $M=0.5$ for two neighboring extrema of opposite types (max-min, min-max). The thickness of $\mathrm{ZnO}$ :Al thin films calculated by Eq. (1) is equal to $455 \mathrm{~nm}$.

To estimate the absorption band edge energy of the films, the first derivative of the optical transmittance can be used. The dependence of $d T / d \lambda$ versus wavelength $\lambda$ is plotted, as shown in the inset of Fig. 1. Position of the characteristic highest first peak of $d T / d \lambda$ corresponds to the optical band gap energy $E_{g}=3.22 \mathrm{eV}$.

The optical band gap $E_{g}$ is also determined from the spectrum of the absorption coefficient $\alpha(h v)$. For this purpose, the known Tauc relation for the direct optical transition between the valence and conduction bands is used [9, 27],

$$
(\alpha \cdot h v)^{2}=A\left(h v-E_{g}\right),
$$

where $A$ is an energy-independent constant and $h v$ is the photon energy. Here, the absorption spectrum $\alpha(h v)$ is calculated from the transmittance data in the spectral range of stronger absorption [28]. The direct optical band gap $E_{g}$ is obtained by plotting the dependence of $(\alpha h v)^{2}$ versus $h v$ and following linear approximation of this dependence to the value $(\alpha h v)^{2}=0$ (Fig. 2). Thus, we have evaluated the exact value of the direct optical band gap for the films studied equal to $E_{g}(d)=3.26 \mathrm{eV}$. The estimated band gap values of the studied $\mathrm{ZnO}: \mathrm{Al}$ films obtained by two above mentioned methods are presented in Table 1.

The spectral dependence $\alpha(h v)$ near the band edge reveals an exponential dependence on the photon energy and obeys Urbach empirical formula (3),

$$
\alpha(h v)=\alpha_{0} \exp \left(\frac{h v}{E_{u}}\right),
$$

where $\alpha_{0}$ and $E_{u}$ (Urbach energy) are the characteristic parameters of the material studied. One can determine the parameters $\alpha$ and $E_{u}$ from the experimental dependence $\alpha(h v)$ (Fig. 3). The value of Urbach energy $E_{u}$ depends on the structural disorder and temperature of the material. Temperature dependence of this energy is formed by the interaction of electrons/excitons with optical phonons [24].

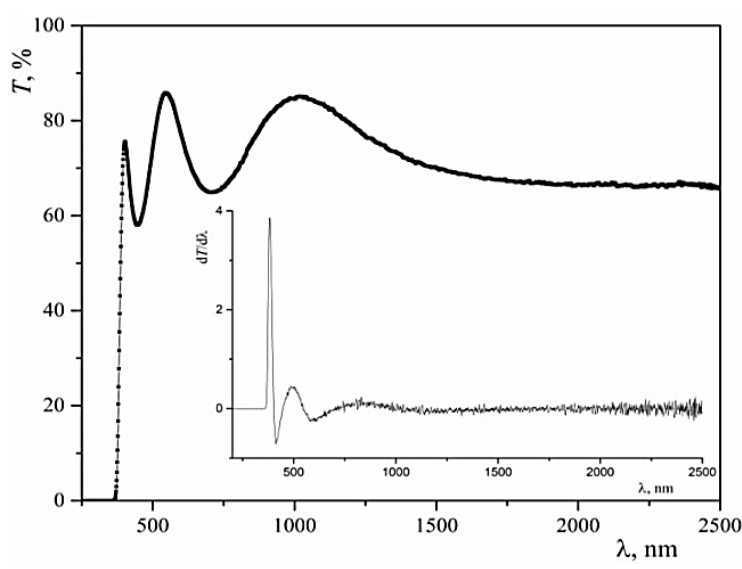

Fig. 1 - Transmission spectrum of $\mathrm{ZnO}: \mathrm{Al}$ thin film. Plot of the transmittance first derivative $d T / d \lambda$ vs. $\lambda$ of $\mathrm{ZnO}: \mathrm{Al}$ thin film

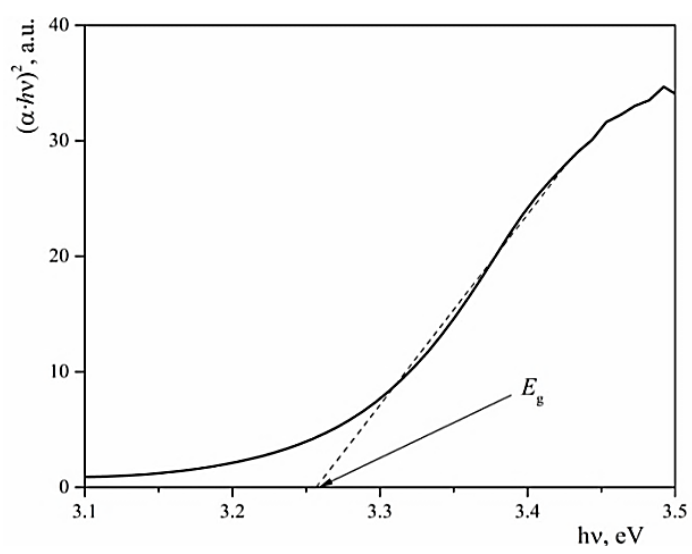

Fig. 2 - Plots of $(\alpha h v)^{2}$ vs. photon energy of $\mathrm{ZnO}$ :Al thin film

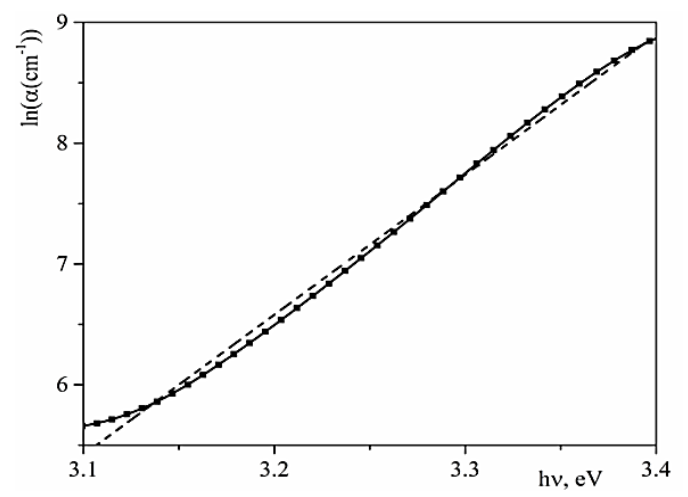

Fig. 3 - Urbach plots of $\mathrm{ZnO}: \mathrm{Al}$ thin film

It is found that Urbach energy of $\mathrm{ZnO}$ :Al films studied increases with increasing doping of zinc oxide by aluminum (Table 1) that may be caused by an increase in the energy width of localized energy states of thin films. However, a more elaborated theory of the experimentally observed exponential dependence $\alpha(h v)$ is still absent. This dependence may arise from the random fluctuations of the internal fields associated 
with structural disorder in many amorphous materials. The exponential dependence of the optical absorption coefficient with photon energy may arise from the electronic transitions between localized states [29]. In many cases, the density of the top valence and bottom conduction band states of materials depend exponentially on the energy in the band gap region that is consistent with Tauc theory.

Table 1 - Optical parameters of $\mathrm{ZnO}$ and $\mathrm{ZnO}: \mathrm{X}(\mathrm{X}=\mathrm{Al}, \mathrm{Cu}$, In, $\mathrm{Sn}, \mathrm{Mn}, \mathrm{Mg}$, Ni, NiO and Fe-Ni) thin films

\begin{tabular}{|c|c|c|c|c|c|c|c|}
\hline Sample & Method of deposition & $d, \mathrm{~nm}$ & $T_{\mathrm{ave}} \%$ & $E_{g}, \mathrm{eV}$ & $E_{g}(d T / d \lambda), \mathrm{eV}$ & $E_{u}, \mathrm{meV}$ & $\mathrm{Ref}$. \\
\hline ZnO:Al (2.5 wt.\%) & $\mathrm{RF}$ & 455 & 77.78 & 3.26 & 3.22 & 86.32 & This work \\
\hline ZnO:Al & Spray Pyrolysis & - & $\geq 80 \%$ & 3.30 & - & 91 & {$[15]$} \\
\hline ZnO:Cu & Spray Pyrolysis & - & $\geq 70 \%$ & 3.27 & - & 98 & {$[15]$} \\
\hline ZnO:Sn & Spray Pyrolysis & - & $\geq 80 \%$ & 3.28 & - & 101 & {$[15]$} \\
\hline ZnO & Sol-Gel & - & $\sim 90$ & 3.29 & - & 367 & {$[24]$} \\
\hline ZnO:In (1.0 \%) & Sol-Gel & - & $\sim 90$ & 3.26 & - & 390 & {$[24]$} \\
\hline ZnO & Coating & - & $\geq 80 \%$ & 3.288 & - & - & {$[23]$} \\
\hline ZnO:Fe-Ni (2\%) & Coating & - & $\geq 80 \%$ & 3.258 & - & - & {$[23]$} \\
\hline ZnO (1:1) & Sol-Gel spin coating method & - & $\geq 85 \%$ & 3.37 & 3.31 & - & {$[30]$} \\
\hline ZnO (0 kGy) & RF & 134 & - & 3.26 & - & 116.71 & {$[14]$} \\
\hline ZnO & Spray Pyrolysis & 210 & - & 3 & - & $\sim 730$ & {$[13]$} \\
\hline ZnO:Sn (4 at.\%) & Spray Pyrolysis & 223 & - & 3.25 & - & $\sim 200$ & {$[13]$} \\
\hline ZnO:Mn (4 at.\%) & Spray Pyrolysis & 192 & - & 3.17 & - & $\sim 210$ & {$[13]$} \\
\hline ZnO:Al (4 at.\%) & Spray Pyrolysis & 178 & - & 3.08 & - & $\sim 400$ & {$[13]$} \\
\hline ZnO & Sol-Gel & - & $\sim 85 \%$ & 3.36 & - & 255 & {$[16]$} \\
\hline ZnO:Mg (6 wt.\%) & Sol-Gel & - & $\sim 85 \%$ & 3.73 & - & 307 & {$[16]$} \\
\hline ZnO & Spray pneumatic method & 149.65 & $\sim 80 \%$ & 3.26 & - & 92 & {$[18]$} \\
\hline ZnO:NiO (3 \%) & Spray pneumatic method & 101.4 & $\sim 80 \%$ & 3.28 & - & 91 & {$[18]$} \\
\hline ZnO & Spray Pyrolysis & $\sim 400$ & $60-70 \%$ & $\sim 3.27$ & - & 23.34 & {$[19]$} \\
\hline ZnO:Ni (5 at.\%) & Spray Pyrolysis & $\sim 400$ & $60-70 \%$ & $\sim 3.27$ & - & $\sim 120$ & {$[19]$} \\
\hline
\end{tabular}

\subsection{Analysis of the Refractive Index}

The dispersions of the refractive index $n(\lambda)$ and extinction coefficient $k(\lambda) \quad(k(\lambda)=\lambda \alpha(\lambda) / 4 \pi)$ (Fig. 4) of a thin film can be easily evaluated from the transmission spectrum with interference effects using the envelope method [9, 31-32]. This method is applicable in the case of a weakly absorbing thin film on an entirely transparent substrate, which is much thicker than a thin film. These conditions are met in this work.

The calculated refractive index $n$ of the thin film studied decreases with increasing wavelength $\lambda$ (see Fig. 4). Here, the dispersion $n(\lambda)$ is normal and may be well approximated by the single oscillator model. In Fig. 5 and Fig. 6, the dashed straight lines are the linear fits of the refractive index dispersions corresponding to the single oscillator model in the form proposed by Wemple and DiDomenico [9],

$$
n(h v)^{2}-1 \cong \frac{E_{d} \cdot E_{0}}{E_{0}^{2}-(h v)^{2}},
$$

where $E_{0}$ is the single oscillator energy, $E_{d}$ is the dispersion energy, and $h v$ is the photon energy. Both Wemple parameters, $E_{0}$ and $E_{d}$, can be obtained from the parameters of the above-mentioned linear fit $\left(n^{2}-1\right)^{-1} \sim(h v)^{2}$ of the dependence (4). The values of these parameters are summarized in Table 2. The refractive index $n_{0}=n(h v=0)$ can be determined by using the expression $n_{0}=\sqrt{1+\frac{E_{d}}{E_{0}}}$. The value $n_{0}$ usually increases with doping of $\mathrm{ZnO}$ by aluminum (Table 2) that may be considered together with the characteristic dimensions of $\mathrm{Al}$ atoms in the $\mathrm{ZnO}$ structure [33].

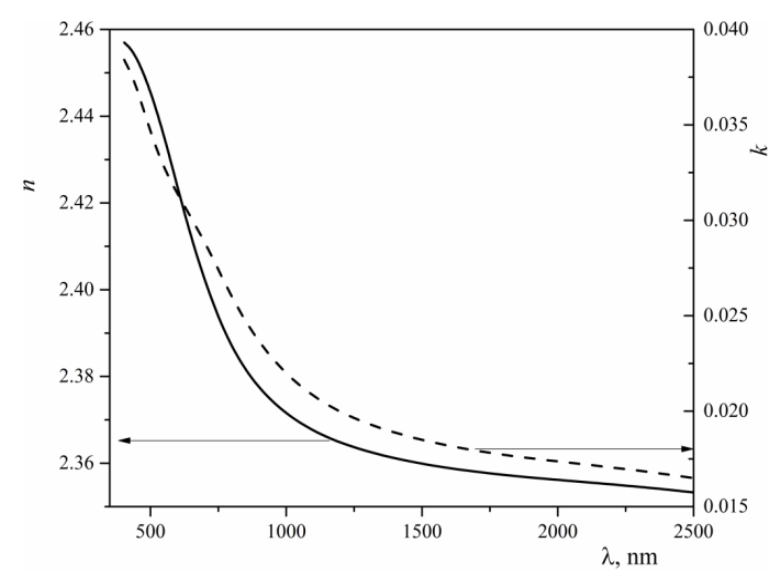

Fig. 4 - Refractive index (left) and extinction coefficient (right) depending on wavelength of $\mathrm{ZnO}: \mathrm{Al}$ thin film

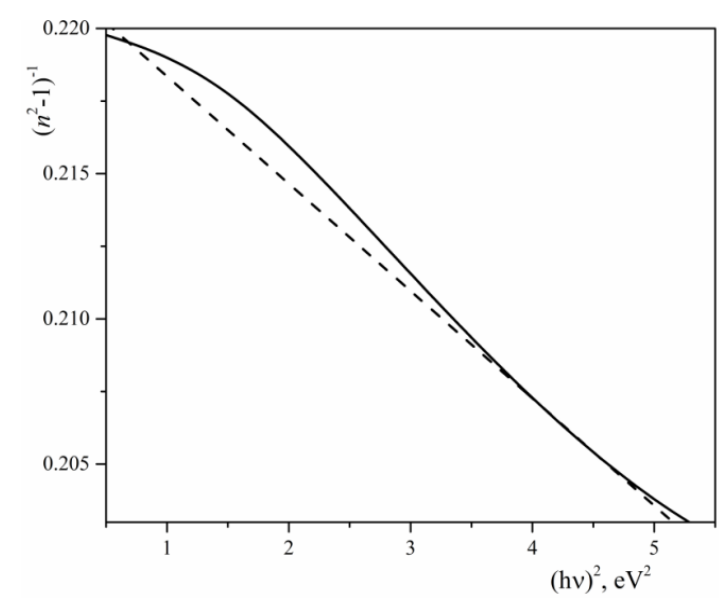

Fig. 5 - Plot of $\left(n^{2}-1\right)^{-1} \sim$ vs. $(h v)^{2}$ for $\mathrm{ZnO}$ :Al thin film 


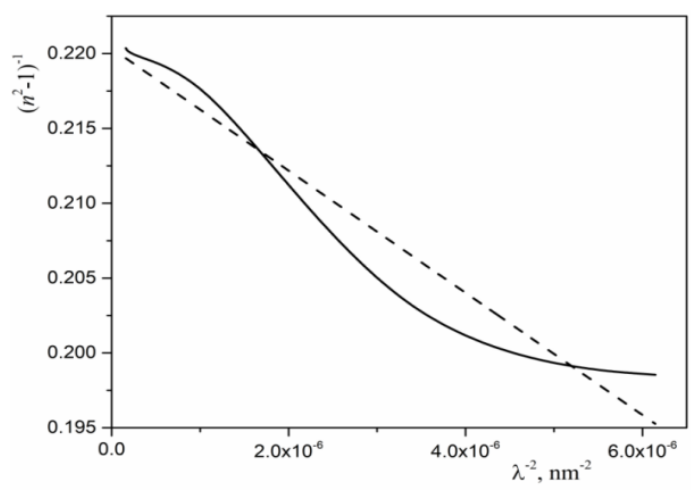

Fig. 6 - Plot of $\left(n^{2}-1\right)^{-1} \sim$ vs. $\lambda^{-2}$ for $\mathrm{ZnO}$ :Al thin film

The $M_{-1}$ and $M_{-3}$ moments of the optical spectra can be obtained from the following relations [29]:

$$
E_{0}^{2}=\frac{M_{-1}}{M_{-3}}, E_{d}^{2}=\frac{M_{-1}^{3}}{M_{-3}} .
$$

The obtained values are given in Table 2 . In addition, the oscillator strength $(f)$ is expressed according to Wemple and DiDomenico via the following formula [24]:

$$
f=E_{0} E_{d}
$$

Aluminium doping of $\mathrm{ZnO}$ film ( $\mathrm{ZnO} \mathrm{Al}, 2.5$ wt.\%) leads to an increase in the oscillator strength value from 35.48 ( $\mathrm{ZnO}[24])$ to $90.68 \mathrm{eV}^{2}$ (Table 2). Similar fluctuations of the oscillator strength for the doped thin films were observed in other studies [29], but there is no clear understanding of such behavior of the oscillator strength till now.

The refractive index dispersion $n(\lambda)$ in the range of transparency can be approximated also by using Sellmeier dispersion Eq. (7),

$$
\left(n^{2}-1\right)^{-1}=\frac{1-\left(\frac{\lambda_{0}}{\lambda}\right)^{2}}{S_{0} \lambda_{0}^{2}},
$$

where $S_{0}$ is the average oscillator strength and $\lambda_{0}$ is the average interband oscillator wavelength. When the dependence of $\left(n^{2}-1\right)^{-1}$ vs. $\lambda^{-2}$ is plotted and the straight-line fit is performed, then the values of $S_{0}$ and $\lambda_{0}$ can be determined from the relation (7) (Table 2).

Table 2 - Single oscillator parameters of $\mathrm{ZnO}$ :Al thin films

\begin{tabular}{|c|c|c|c|c|c|c|c|c|c|c|}
\hline Sample & $\begin{array}{c}\text { Method of } \\
\text { deposition }\end{array}$ & $E_{0}, \mathrm{eV}$ & $E_{d}, \mathrm{eV}$ & $n_{0}$ & $M_{-1}$ & $M_{-3}, \mathrm{eV}-2$ & $f$ & $\lambda_{0}, \mathrm{~nm}$ & $S_{0}, \mathrm{~nm}^{-2}$ & $\mathrm{Ref}^{-}$ \\
\hline $\begin{array}{c}\text { ZnO:Al } \\
(2.5 \text { wt. \% })\end{array}$ & $\mathrm{RF}$ & 4.48 & 20.24 & 2.35 & 4.52 & 0.23 & 90.68 & 136.1 & $2.510^{-4}$ & $\begin{array}{c}\text { This } \\
\text { work }\end{array}$ \\
\hline ZnO & Sol-Gel & 6.62 & 5.36 & 1.35 & 0.89 & 0.020 & 35.48 & 285 & $1.06 \cdot 10^{-5}$ & {$[24]$} \\
\hline $\begin{array}{c}\text { ZnO:In } \\
(1.0 \%)\end{array}$ & Sol-Gel & 6.80 & 8.56 & 1.50 & 0.81 & 0.017 & 58.20 & 305 & $1.34 \cdot 10^{-5}$ & {$[24]$} \\
\hline
\end{tabular}

\subsection{The Complex Dielectric Function}

It is known that the real and imaginary parts, $\varepsilon_{1}$ and $\varepsilon_{2}$, of the complex dielectric permittivity $\varepsilon$,

$$
\varepsilon=\varepsilon_{1}+i \cdot \varepsilon_{2}
$$

are related to the refractive index $n$ and extinction coefficient $k$ by Eqs. (9) and (10),

$$
\begin{gathered}
\varepsilon_{1}=n^{2}-k^{2}, \\
\varepsilon_{2}=2 \cdot n \cdot k .
\end{gathered}
$$

For the values of $n$ much greater than $k$, the value of $\varepsilon_{1}$ is approximately equal to $n^{2}$, and the dependence of $\varepsilon_{1}(\lambda)$ can be fitted using the relation [9] valid for the free electron light absorption,

$$
\varepsilon_{1}=n^{2}=\varepsilon_{\infty}-\left(\frac{e^{2}}{\pi \cdot c^{2}}\right) \cdot\left(\frac{N_{c}}{m^{*}}\right) \cdot \lambda^{2},
$$

where $c$ is the speed of light, $m^{*}$ is the effective mass of the carrier, $N_{c}$ is the carrier density, $e$ is the electronic charge, and $\varepsilon_{\infty}$ is the high-frequency dielectric constant. To obtain the high frequency dielectric constant $\varepsilon_{\infty}$, we plot a graph $n^{2}$ as a function of $\lambda^{2}$ and extrapolate the linear part of the curve to $\lambda^{2}=0$ (Fig. 7).

Furthermore, the dispersion of the imaginary part of the dielectric function $\varepsilon_{2}(\lambda)$ is used to estimate the relaxation time $(\tau)$, optical mobility $\left(\mu_{o p t}\right)$ and optical resistivity $\left(\rho_{o p t}\right)$ in the framework of the Drude free electron model $[23,34]$ using the relation

$$
\varepsilon_{2}=\left(\frac{e^{2}}{4 \varepsilon_{0} \pi^{3} \cdot c^{3}}\right) \cdot\left(\frac{N_{c}}{m^{*}}\right) \cdot\left(\frac{1}{\tau}\right) \lambda^{3} .
$$

The parameter $\tau$ is found from the slope of the plot $\varepsilon_{2}\left(\lambda^{3}\right)$, where the value of $N_{\mathrm{c}} / m^{*}$ is taken from Eq. (11). Afterwards, the optical mobility $\mu_{o p t}$ and optical resistivity $\rho_{\text {opt }}$ of $\mathrm{ZnO}: \mathrm{Al}$ thin films are calculated by the relations (13) and (14) [34],

$$
\begin{gathered}
\mu_{o p t}=\frac{e \tau}{m^{*}}, \\
\rho_{o p t}=\frac{1}{e \mu_{o p t} N_{c}} .
\end{gathered}
$$

The calculated values of the relaxation time $\tau$, optical mobility $\mu_{o p t}$ and optical resistivity $\rho_{o p t}$ are presented in Table 3.

It is found that the aluminium doping of $\mathrm{ZnO}$ thin films increases the values of optical mobility and relaxation time (Table 3 ). In addition, it is revealed that 2.5 wt. \% doping of $\mathrm{ZnO}$ by aluminium leads to higher values of optical mobility and relaxation time than those for $\mathrm{ZnO}$ thin films doped with $\mathrm{Fe}-\mathrm{Ni}$ [23].

Additionally, the electron plasma frequency $\left(\omega_{p}\right)$ is calculated using relation (15) [35], 


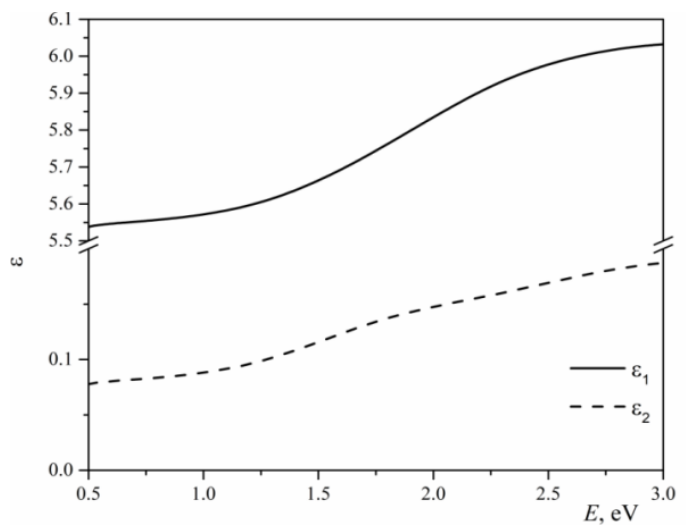

Fig. 7 - Real $\left(\varepsilon_{1}\right)$ and imaginary $\left(\varepsilon_{2}\right)$ parts of dielectric functions depending on photon energy of $\mathrm{ZnO}: \mathrm{Al}$ thin film

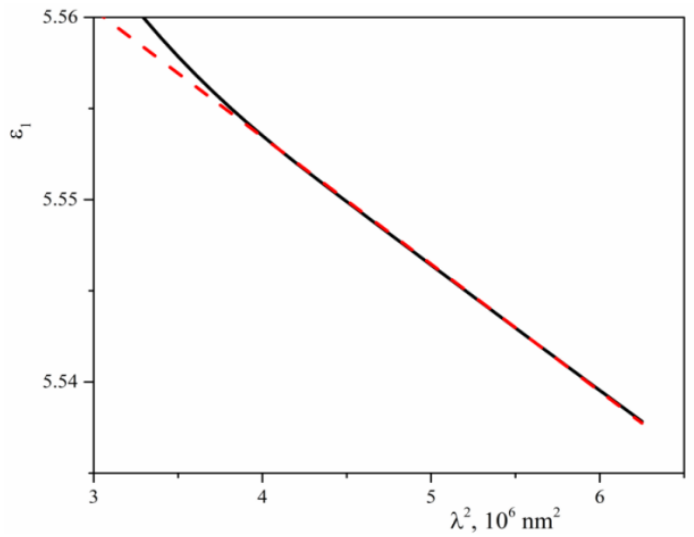

Fig. 8 - Variation of the real part of the dielectric coefficient $\left(\varepsilon_{1}\right)$ with $\lambda^{2}$ for $\mathrm{ZnO}$ :Al thin film

$$
\omega_{p}=\left(\frac{e^{2} N_{c}}{\varepsilon_{0} m^{*}}\right)^{1 / 2} .
$$

As expected, aluminium doping of $\mathrm{ZnO}$ thin films leads to an increase in $\omega_{p}$ value in comparison to pure $\mathrm{ZnO}$ (Table 3).

The dielectric loss factor $\tan \delta$ is determined by the known relation

$$
\tan \delta=\frac{\varepsilon_{2}}{\varepsilon_{1}},
$$

and the corresponding photon energy dependence $\tan \delta(E)$ is presented in Fig. 9. The complex optical conductivity $\left(\sigma=\sigma_{1}+i \sigma_{2}\right)$ is known to be related to the complex dielectric constant (8) [29],

$$
\sigma_{1}=\omega \varepsilon_{2} \varepsilon_{0}, \sigma_{2}=\omega \varepsilon_{1} \varepsilon_{0},
$$

where $\omega$ is the angular frequency, $\varepsilon_{0}$ is the dielectric constant. Both components $\sigma_{1}$ and $\sigma_{2}$ of the optical conductivity $\sigma$ increase with increasing frequency $\omega$ (Fig. 10).

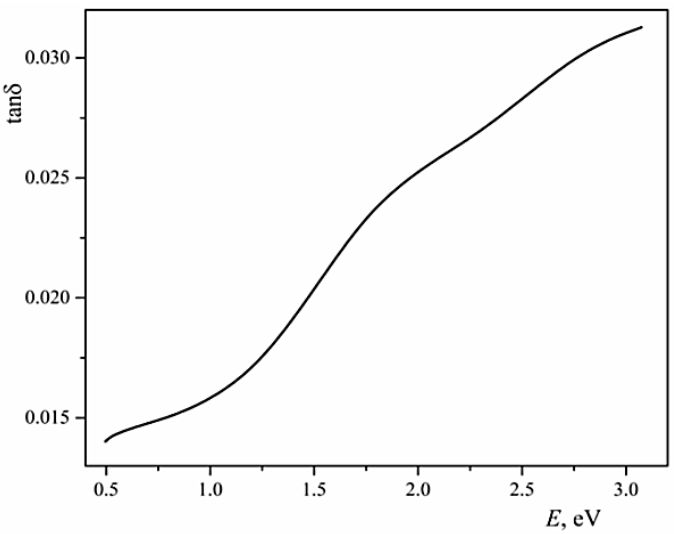

Fig. 9 - Variation of dielectric loss with energy for $\mathrm{ZnO}: \mathrm{Al}$ thin film

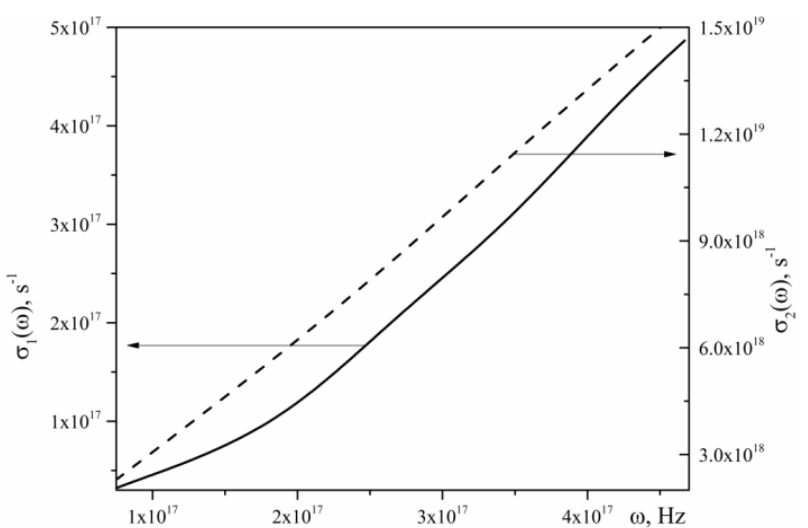

Fig. 10 - The optical conductivity dependence of frequency for $\mathrm{ZnO}$ :Al thin film

Table 3 - Optoelectronic constants of $\mathrm{ZnO}$ :Al thin films obtained from analysis of optical dielectric functions

\begin{tabular}{|c|c|c|c|c|c|c|c|c|}
\hline Sample & $\begin{array}{c}\text { Method of } \\
\text { deposition }\end{array}$ & $\varepsilon_{\infty}$ & $\begin{array}{c}\left(\frac{N_{c}}{m^{*}}\right), \\
\mathrm{kg}^{-1} \mathrm{~m}^{-3}\end{array}$ & $\mu_{\text {opt }}, \mathrm{m}^{2} / \mathrm{V} \cdot \mathrm{s}$ & $\begin{array}{c}\rho_{\text {opt }}, \\
\Omega^{-1} \cdot \mathrm{m}^{-1}\end{array}$ & $\tau, \mathrm{s}$ & $\omega_{p}, \mathrm{~s}^{-1}$ & $R e f$. \\
\hline $\mathrm{ZnO}: \mathrm{Al}$ & $\mathrm{RF}$ & 5.48 & $1.23 \cdot 10^{57}$ & $6.7 \cdot 10^{-3}$ & $3 \cdot 10^{-5}$ & $1.68 \cdot 10^{-14}$ & $6 \cdot 10^{8}$ & $\begin{array}{c}\text { This } \\
\text { work }\end{array}$ \\
\hline $\mathrm{ZnO}$ & Coating & 2.993 & $1.208 \cdot 10^{57}$ & $3.643 \cdot 10^{-3}$ & $3.544 \cdot 10^{-6}$ & $0.913 \cdot 10^{-14}$ & $5.720 \cdot 10^{7}$ & {$[23]$} \\
\hline $\begin{array}{c}\mathrm{ZnO}: \mathrm{Fe}-\mathrm{Ni} \\
(2 \%)\end{array}$ & Coating & 3.562 & $2.167 \cdot 10^{57}$ & $5.095 \cdot 10^{-3}$ & $1.412^{-6} \cdot 10^{-6}$ & $1.276 \cdot 10^{-14}$ & $8.620 \cdot 10^{7}$ & {$[23]$} \\
\hline $\mathrm{ZnO}$ & Sol-Gel & 2.14 & $2.11 \cdot 10^{56}$ & - & - & - & - & {$[24]$} \\
\hline $\begin{array}{c}\mathrm{ZnO}: \mathrm{In} \\
(1.0 \%)\end{array}$ & Sol-Gel & 2.71 & $5.77 \cdot 10^{56}$ & - & - & - & - & {$[24]$} \\
\hline
\end{tabular}




\section{CONCLUSIONS}

Optical characteristics of zinc oxide thin films with 2.5 wt. \% aluminium content obtained by the RF method have been studied by the transmittance measurements in the wavelength spectral range of $300-2500 \mathrm{~nm}$ by the interferometry method. The data obtained have been used to calculate the complex dielectric function $\varepsilon=\varepsilon_{1}+i \varepsilon_{2}$, complex refractive index $n=n_{1}+i n_{2}$ and several associated optical values of $\mathrm{ZnO}: \mathrm{Al}$ thin films. The data obtained have been also elaborated using the Urbach approximation.

One of the main findings is the increase in Urbach energy for $\mathrm{ZnO}: \mathrm{Al}$ thin films in comparison to the undoped ones. This probably is caused by an increase in the energy width of the localized electronic energy states of thin films due to increased atomic disorder. Also, an almost twofold increase in the optical oscilla-

\section{REFERENCES}

1. V.M. Zhyrovetsky, D.I. Popovych, S.S. Savka, A.S. Serednytski, Nanoscale Res. Lett. 12, 132 (2017).

2. D.M. Bagnall, Y.F. Chen, M.Y. Shen, Z. Zhu, T. Goto, T. Yao, J. Crystal Growth 184-185, 605 (1998).

3. C.H. Ahn, Y.Y. Kim, S.W. Kang, H.K. Cho, Physica B 401402, 370 (2007).

4. H.S. Kang, G.H. Kim, D.L. Kim, H.W. Chang, B.D. Ahn, S.Y. Lee, Appl. Phys. Lett. 89, 181103 (2006).

5. V.M. Latyshev, T.O. Berestok, A.S. Opanasyuk, A.S. Kornyushchenko, V.I. Perekrestov, Solid State Sci. 67, 109 (2017).

6. O. Dobrozhan, O. Diachenko, M. Kolesnyk, A. Stepanenko, S. Vorobiov, P. Baláž, S. Plotnikov, A. Opanasyuk, Mater. Sci. Semicond. Proc. 102, 104595 (2019).

7. R. Vittal, Kuo-Chuan Ho, Renew. Sustain. Energy Rev. 70, 920 (2017).

8. N. Bouchenak Khelladi, N.E. Chabane Sari, Adv. Mater. Sci. 13, 21 (2013)

9. A. Kashuba, H. Ilchuk, R. Petrus, I. Semkiv, O. Bovgyra, M. Kovalenko, V. Dzikovskyi, Modern Phys. Lett. B 35, 2150189 (2021).

10. V. Bilgina, E. Sarica, B. Demirselcuk, K. Ertürk, Physica B: Condens. Matter. 599, 412499 (2020).

11. V. Romanyuk, N. Dmitruk, V. Karpyna, G. Lashkarev, V. Popovych, M. Dranchuk, R. Pietruszka, M. Godlewski, G. Dovbeshko, I. Timofeeva, O. Kondratenko, M. Taborska, A. Ievtushenko, Acta Physica Polonica A 129, A-36 (2016).

12. H.C.M. Knoops, van de B.W.H. Loo, S. Smit, M. Ponomarev, J.W. Weber, K. Sharma, W.M.M. Kessels, M. Creatore, J. Vac. Sci. Technol. A 33, 021509 (2015).

13. M.N. Amroun, K. Salim, A.H. Kacha, M. Khadraoui, Int. J. Thin. Film. Sci. Tec. 9, 7 (2020).

14. A.E. Youssef, M.H. Abd-El Salam, Rad. Effect. Defect. Solids 175, 791 (2020).

15. F.Z. Bedia, A. Bedia, N. Maloufi, M. Aillerie, Adv. Struct. Mater. 128, 107 (2020).

16. M.R. Islam, M.G. Azam, Surf. Eng. 37, 775 (2020).

17. X. Li, X. Zhu, K. Jin, D. Yang, Opt. Mater. 100, 109657 (2020). tor strength value has been revealed for the thin film studied.

Several electronic and optical parameters of the Drude free electron model (relaxation time, optical mobility and optical resistivity) for the thin films studied have been estimated for the first time. The doping of $\mathrm{ZnO}$ thin films with $\mathrm{Al}$ leads to an increase in the optical mobility, relaxation time and plasma frequency that was revealed by comparison with reference data for undoped $\mathrm{ZnO}$.

Numerous optical parameters of $\mathrm{ZnO}: \mathrm{Al}$ thin films obtained allow us to recommend these samples for applications in optoelectronic devices.

\section{ACKNOWLEDGEMENTS}

This work was supported by the Project of Young Scientists (No 0121U108649) of Ukraine.

18. Y. Aoun, R. Meneceur, S. Benramache, B. Maaoui, Phys. Solid State 62, 131 (2020).

19. L. Herissi, L. Hadjeris, M.S. Aida, S. Azizi, A. Hafdallah, A. Ferdi, Nano Hybrid. Compos. 27, 21 (2019).

20. M. Gabas, A. Landa-Cánovas, J.L. Costa-Krämer, F. AgullóRueda, A.R. González-Elipe, P. Díaz-Carrasco, J. HernándezMoro, I. Lorite, P. Herrero, P. Castillero, A. Barranco, J.R. Ramos-Barrado, J. Appl. Phys. 113, 163709 (2013).

21. O. Bovgyra, M. Kovalenko, R. Bovhyra, V. Dzikovskyi, J. Phys. Stud. 23 No 4, 4301 (2019).

22. V.B. Kapustianyk, B.I. Turko, V.P. Rudyk, B.Y. Kulyk, M.S. Rudko, J. App. Spectr. 82, 153 (2015).

23. A.M. Alsaad, A.A. Ahmad, Q.M. Al-Bataineh, A.A. BaniSalameh, H.S. Abdullah, I.A. Qattan, Z.M. Albataineh, A.D. Telfah, Materials 13, 1737 (2020).

24. A. Kocyigit, M.O. Erdal, M. Yıldırım, Zeitschrift für Naturforschung 74, 1 (2019).

25. C. Manoharan, G. Pavithra, M. Bououdina, S. Dhanapandian, P. Dhamodharan, Appl. Nanosci. 6, 815 (2016).

26. H. Munawaroh, S. Wahyuningsih, A.H. Ramelan, J. NanoElectron. Phys. 11, 04028 (2019).

27. M. Kovalenko, O. Bovgyra, V. Dzikovskyi, A. Kashuba, H. Пchuk, R. Petrus, I. Semkiv, Phys. Chem. Solid State 22, 153 (2021).

28. F.Z. Bedia, A. Bedia, N. Maloufi, M. Aillerie, F. Genty, B. Benyoucef, J. Alloy. Compd. 616, 312 (2014).

29. Y. Caglar, S. Ilican, M. Caglar, Eur. Phys. J. B 58, 251 (2007).

30. I.S. Yahia, A.A.M. Farag, M. Cavas, F. Yakuphanoglu, Superlattice. Microst. 53, 63 (2013).

31. H. Ilchuk, R. Petrus, A. Kashuba, I. Semkiv, E. Zmiiovska, Molec. Cryst. Liq. Cryst. 699, 1 (2020).

32. L.I. Nykyruy, R.S. Yavorskyi, Z.R. Zapukhlyak, G. Wisz, P. Potera, Opt. Mater. 92, 319 (2019).

33. C.E. Benouis, M. Benhaliliba, A.S. Juarez, M.S. Aida, F. Chami, F. Yakuphanoglu, J. Alloy. Compd. 490, 62 (2010).

34. A.Y. Fasasi, E. Osagie, D. Pelemo, E. Obiajunwa, E. Ajenifuja, J. Ajao, G. Osinkolu, W.O. Makinde, A.E. Adeoye, Am. J. Mater. Synth. Process. 3, 12 (2018).

35. F. Yakuphanoglu, M. Sekerci, J. Molec. Struct. 751, 200 (2005). 


\title{
Оптичні та дисперсійні параметри тонких плівок $\mathrm{ZnO}: \mathrm{Al}$
}

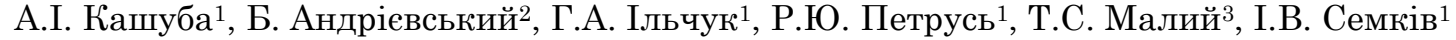

${ }^{1}$ Національний університет "Львівська політехніка", вул. С. Бандери, 12, 79646 Львів, Украйна

2 Факультет електроніки та колп'ютерних наук, Кошалінський технологічний університет, 75-453 Кошалін, Польща

3 Львівський національний університет ілені Івана Франка, вул. Кирила і Меббодія, 8, 79005 Львів, Украӥна

\begin{abstract}
Представлені результати досліджень дисперсії параметрів та оптичних функцій для тонкої плівки оксиду цинку, легованої алюмінієм. Осадження тонких плівок $\mathrm{ZnO}$, легованих $\mathrm{Al}$ (2,5 мас. \%), виконувалось методом високочастотного магнетронного напилення. Тонка плівка $\mathrm{ZnO}$ :Al кристалізуеться в гексагональній структурі (тип структури $\mathrm{ZnO}$, просторова група $P 6_{3} m c$ (No. 186), з параметрами елементарної комірки $a=3.226(2) \AA$ і $c=5.155(6) \AA\left(V=46.49(6) \AA^{3}\right)$. Спектри оптичного пропускання (300-2500 нм) показали, що тонка плівка $\mathrm{ZnO}: \mathrm{Al}$ має високу оптичну якість, а значення величини оптичної ширини забороненої зони $(3,26 \mathrm{eB})$ е дуже близьким до нелегованих зразків. Встановлено спектральну поведінку оптичних функцій: показника заломлення, коефіціента екстинкції, показника поглинання, діелектричних функції та оптичної провідності. Встановлено значення енергії Урбаха та залежність сили осцилятора від оптичної ширини забороненої зони та концентрації легуючого елемента. Спостерігається збільшення енергії Урбаха для легованої $\mathrm{Al}$ тонкої плівки $\mathrm{ZnO}$ порівняно з нелегованою. Для досліджуваної тонкої плівки виявлено майже подвійне збільшення значення сили оптичного осцилятора в порівняні із нелегованими зразками. Вплив легування алюмініем тонких плівок $\mathrm{ZnO}$ на динаміку зміни оптичної рухливості, оптичного опору та часу релаксації встановлено вперше для досліджуваної сполуки. Також, визначається значення плазмової частоти та її кореляція з концентрацією носіїв. Легування тонких плівок $\mathrm{ZnO}$ алюмініем призводить до збільшення оптичної рухливості, часу релаксації та плазмової частоти, що було виявлено порівнянням з відомими даними для нелегованих тонких плівок $\mathrm{ZnO}$. Виявлені оптичні властивості досліджуваної тонкої плівки вказують на перспективи їі практичного використання як матеріалу для оптоелектронних пристроїв.
\end{abstract}

Ключові слова: Тонкі плівки, Поглинання, Дисперсія, Показник заломлення, Пропускання, Оптичні функції, Час релаксації. 